\title{
Clinical Implication and Proposed Mechanism of Direction Changing Vibration Induced Nystagmus in Unilateral Vestibular Hypofunction
}

\author{
Dong Han Lee, Moo Kyun Park, Jun Ho Lee, Seung-Ha Oh, and Myung-Whan Suh \\ Department of Otorhinolaryngology-Head and Neck Surgery, Seoul National University Hospital, Seoul, Korea
}

일측 전정기능 저하 환자에서 방향전환 진동유발안진의 임상적 의의와 발생 기전 제안

이동한 · 박무균 · 이준호 · 오승하 · 서명환

서울대학교병원 이비인후과

Received September 15, 2017

Revised December 27, 2017

Accepted January 8, 2018

Address for correspondence

Myung-Whan Suh, MD, PhD

Department of Otorhinolaryngology-

Head and Neck Surgery,

Seoul National University Hospital,

101 Daehak-ro, Jongno-gu,

Seoul 03080, Korea

Tel $+82-2-2072-2448$

Fax $+82-2-2072-2447$

E-mail drmung@naver.com
Background and Objectives We evaluated the clinical characteristics and vestibular function of patients with direction changing vibration induced nystagmus (DC VIN) and unilateral vestibular hypofunction and suggest clinical implication and a proposed mechanism of DC VIN. Subjects and Method The records of 315 patients who underwent the VIN test were reviewed retrospectively. Among these, 18 patients (5.7\%) showed DC VIN, and out of whom, 15 patients $(4.8 \%)$ were diagnosed as unilateral vestibular hypofunction by caloric, rotation chair (RCT), and video head impulse test (vHIT). We analyzed the relationship between DC VIN and the dizziness characteristics, duration of disease, and the outcome of the vestibular function test. Results The mean age of 15 patients was $67.4 \pm 10.7$ years and the mean duration of dizziness was $13.6 \pm 29.7$ months. The caloric test revealed $25 \%$ of the patients to have significant canal paresis [Caloric vestibular neuritis (VN)], while 75\% showed normal caloric response. However, unilateral vestibular hypofunction was observed by abnormal results in RCT or vHIT (Non-caloric VN). Seven patients showed ipsilateral DC VIN (nystagmus to vibrated side) and eight patients contralateral DC VIN (nystagmus to opposite side of vibration). Patients with ipsilateral DC VIN were shown to have a significant longer duration of dizziness than those with contralateral DC VIN.

Conclusion Although rare, DC VIN can also be found in patients with unilateral vestibular hypofunction. Patients with DC VIN had a mild vestibular asymmetry with Non-caloric VN or Caloric VN in the process of compensation. The mechanism of ipsilateral DC VIN seems to be due to the small amount of vestibular asymmetry, which is smaller than the interaural attenuation of vibration. Korean J Otorhinolaryngol-Head Neck Surg 2018;61(11):580-7

Key Words Caloric test - Nystagmus · Vestibular neuronitis - Vibration.

\section{서 론}

전정신경염과 같은 급성 일측 전정기능 저하(unilateral vestibular hypofunction)가 발생한 경우 급성기에는 자발안진

This is an Open Access article distributed under the terms of the Creative Commons Attribution Non-Commercial License (https://creativecommons.org/licenses/by-nc/4.0) which permits unrestricted non-commercial use, distribution, and reproduction in any medium, provided the original work is properly cited. (spontaneous nystagmus)이 관찰되지만, 보상이 이루어지면 더 이상 자발안진을 관찰할 수 없다. 이 경우 내재된 일측 전정 기능 저하를 확인하기 위한 이학적 검사로 두진후안진(post head shake nystagmus, HSN) 또는 진동유발안진(vibration induced nystagmus, VIN)을 시행할 수 있다. 이중 진동유발안 진은 양측 유양돌기, 이마, 후경부 등에 진동기로 진동 자극 을 주면 유발되는 안진으로 1973년 Lücke 등이 처음 기술하 
였다. 두진후안진(HSN)은 두진이 멈춘 이후 안진이 발생하는 반면, 진동유발안진은 진동 자극이 주어지는 동안만 유발되 고 진동 자극이 멈추면 안진도 멈추는 특징이 있다. 또한, 이 마나 후경부에 비해 양측 유양돌기 부근을 자극할 때 안진 의 크기가 가장 큰 것으로 알려져 있다. ${ }^{1-3)}$

일반적으로 일측 전정기능 저하 환자에서는 VIN의 방향이 건 측 귀를 향하는 것으로 알려졌다. ${ }^{2,45}$ 진동 자극을 건 측에 인가하는 경우나 병 측에 인가하는 경우 모두 안진은 항상 건 측을 향한다고 보고와,4) 48 명의 일측 전정기능 저하 환자 에서 예외 없이 VIN이 건 측을 향한다는 보고가 있었다. ${ }^{5)}$ 메니에르병 환자에서만 안진이 병 측을 향하는 경우가 약 $30 \%$ 에서 발견되었다. ${ }^{5)}$

그러나 정상인에서 어떤 VIN이 발견되는지와 그 기전이 무 엇인지에 대해서는 이견이 있다. ${ }^{3-6)}$ 보고자에 따라 정상인에 서도 진동 자극을 인가한 방향을 향하는 VIN이 종종 있다고 보고하기도 하며,) 다른 보고자는 정상인 30명을 분석한 결 과 VIN이 유발되는 경우는 단 1예도 없었다고 발표하기도 하였다. ${ }^{5)}$ 정상인에서 안진이 유발되는 기전으로는 진동 자극 이 경부 고유감각을 자극하여 자극 방향에 따라 안진의 방 향이 바뀌는 VIN을 유발하기 때문으로 추정되고 있다. ${ }^{4)}$

실제 어지럼증 환자들을 진료 중에는 자극하는 귀에 따라 안진의 방향이 바뀌는 VIN(direction changing VIN, DC VIN) 을 종종 관찰하게 된다. 기존 문헌에는 DC VIN의 임상적 의 미와 발생 기전에 대해 연구된 바가 거의 없다. 이에 본 연구 에서는 DC VIN이 발견되는 환자들의 다양한 전정기능 검사 결과를 분석해보고 그 임상적 의미와 발생 기전을 고찰해보 고자 하였다.

\section{대상 및 방법}

\section{대 상}

2014년 10월부터 2016년 1월까지 VIN을 시행한 환자 315명 의 의무기록을 후향적으로 분석하였다. 이중 약 $5.7 \%$ 인 18 명 에서 좌측, 우측 VIN 결과 수평안진의 방향이 서로 반대로 나타나는 DC VIN이 발견되었다. 이들 18 명 중 15 명(전체분 석 대상 315 명의 $4.8 \%$ )은 온도안진검사, 회전의자검사, 두부 충동검사, 주관적시수직검사, 동적자세검사에서 일측 전정기 능 저하가 확인되어 전정신경염으로 진단할 수 있었다. 본 연 구는 일측 전정기능 저하가 확인되었고 DC VIN이 발견된 전정신경염 환자들을 대상으로 진행되었다.

\section{VIN 검사방법}

50 100 Hz의 진동 주기를 갖는 진동 자극기(M-806, Boman
Products Co., Ltd, China)를 사용하여 환자가 앉은 상태에 서 양측 유양돌기 부위에 무작위 순서로 각각 10 20초간 진 동을 주고, 진동자극이 인가되는 동안 안구의 움직임을 비디 오안진검사장비(ICS CHARTR 200, Otometrics, Taastrup, Denmark 또는 Easy-eyes, SLmed, Seoul, Korea)로 기록하 였다. 수평 성분의 안진만을 분석하였으며 자발 안진을 보이 는 경우는 없었다.

\section{어지럼증 발병양상과 전정신경염의 세부 진단 분류}

어지럼의 발병양상은 둘로 나누어 분석하였다. 어지럼증이 급성(발병 시작 이후 수 시간 이내 어지럼이 최고점에 도달) 회 전성 현훈(self-motion when no self-motion is occurring)으 로 발병한 경우 급성발작(acute attack)으로 정의하였다. 반면 비회전성 비특이적인 어지럼(disturbed or impaired spatial orientation without a false or distorted sense of motion)이 서서히(발병 시작 수일 이후 어지럼이 최고점에 도달) 발생한 경우 잠행성 발병(insidious onset)으로 정의하였다. 전정신경 염의 세부 진단은 온도안진검사 결과에 따라 다음과 같이 이 분하였다. 온도안진검사에서는 반고리관 마비 값 $20 \%$ 를 초 과 시 Caloric vestibular neuritis(VN)으로, 반고리관 마비 값 은 20\% 이하이지만 회전의자검사, 두위안진, 비디오 두부 충 동검사 또는 동적자세검사에서 전정 기능의 좌우 불균형이 확인된 경우 경미한 전정기능 저하가 있는 것으로 판단하여 Non-caloric VN으로 분류하였다.

\section{결과 분석}

각 환자에서 진단, 병 측, 나이, 성별, 어지럼증 발병양상, 유 병 기간, 자발안진, 두위안진, 두진후안진, VIN, 온도안진 검 사, 정현파회전검사, 등속회전검사, 침대맡 두부충동검사, 비 디오 두부충동검사, modified Clinical Test of Sensory Interaction in Balance(mCTSIB) 결과를 분석하였고 DC VIN 결과와의 연관성을 분석하였다. 온도안진검사는 반고리관 마 비 값이 $20 \%$ 를 초과할 경우 전정기능 저하로 분류하였으며, 정현파회전검사는 $0.01,0.04,0.16 \mathrm{~Hz}$ 세 주파수에 검사를 시 행하였으며, 1 개 이상의 주파수에서 gain의 저하나 phase lead 혹은 asymmetry의 이상소견이 발견되는 경우 전정기능 저하 로 분류하였다. 긍속회전검사는 최고속도 $100 \% \mathrm{sec}$ 로 시행 하였으며, 이득과 시간상수의 방향 우위가 $15 \%$ 보다 높은 경 우 일측 전정기능 저하로 분류하였다. ${ }^{78)}$ 비디오두부충동검사 는 수평반고리관에 대해서만 분석하였으며, 면적 이득이 0.8 이하인 경우 또는 크기가 $100 \% \mathrm{sec}$ 이상인 교정성단속이 명 확히 발견되는 경우 전정기능 저하로 분류하였다. ${ }^{9)} \mathrm{mCTSIB}$ 는 NeuroCom Balance Master ${ }^{\circledR}$ System(Natus Medical Inc., 
San Carlos, CA, USA)의 검사장비를 사용하였으며, 전정기 능을 반영하는 조건 즉 시각정보와 체성감각 정보가 차단된 조건(foam pad eye closed)에서만 유일하게 중력중심동요속 도(center of gravity sway velocity)가 피험자의 키와 나이에 따라 정해지는 sway reference 정상치를 벗어날 경우 전정기 능 저하로 분류하였다. ${ }^{10)}$ 주관적시수직검사는 암실에서 직선 레이저를 이용하여 시행하였으며, $2.5^{\circ}$ 보다 편위가 심한 경우 일측 전정기능 저하로 분류하였다. ${ }^{11)}$ 또한 두위안진이 한쪽방 향의 안진으로 일관되게 나타나는 경우도 일측 전정기능 저 하로 분류하였다. 통계 결과는 SPSS software ver. 20.0(IBM

Table 1. Demographics of the patients with direction changing vibration induced nystagmus and unilateral vestibular hypofunction

\begin{tabular}{|c|c|c|}
\hline Variables & Number & Comments \\
\hline Age $(y r)$ & $67.4 \pm 10.7$ & \\
\hline $\operatorname{Sex}(M: F)$ & $7: 8$ & \\
\hline Duration of illness (mo) & $13.6 \pm 29.7$ & >1 mo: 14 (93.3\%) \\
\hline \multicolumn{3}{|l|}{ Character of dizziness } \\
\hline Acute attack of vertigo & $7(46.7 \%)$ & \\
\hline $\begin{array}{l}\text { Insidious onset of mild } \\
\text { dizziness }\end{array}$ & $8(53.3 \%)$ & \\
\hline \multicolumn{3}{|l|}{ Caloric test } \\
\hline $\begin{array}{l}\text { Normal }(\mathrm{CP} \leq 20 \%) \\
\text { Non-caloric } \mathrm{VN}\end{array}$ & $9(75 \%)$ & Abnormal RCT or vHIT \\
\hline $\begin{array}{l}\text { Abnormal }(\mathrm{CP}>20 \%) \text {, } \\
\text { Caloric VN }\end{array}$ & $3(25 \%)$ & \\
\hline Not checked & 3 & Abnormal vHIT \\
\hline
\end{tabular}

CP: canal paresis, RCT: rotation chair test, $v H I T$ : video head impulse test, VN: vestibular neuritis
Corp., Armonk, NY, USA)의 비모수검정인 Mann Whitney U-test와 chi-squared test 중 Fisher's exact test를 이용하여 분석하였으며 유의수준이 $5 \%$ 이하인 경우 유의한 것으로 해 석하였다.

\section{결 과}

DC VIN이 발견된 일측 전정기능 저하 환자들 15 명의 평균 연령은 $67.4 \pm 10.7$ 세였으며, 7 명이 남성이었다. 유병 기간은 $13.6 \pm 29.7$ 개월로 93.3\%(14명)에서 1개월을 초과하는 유병 기간을 보여 일반적인 급성 전정신경염 환자들이 병원에 내 원하는 시점인 1 5일에 비해 병원에 내원하는 시점이 지연되 었음을 알 수 있었다. ${ }^{12)}$ 어지럼증의 발병 양상은 acute $\operatorname{attack}(7$ 명, 46.7\%)으로 발병했던 경우보다 insidious onset(8명, 53.3\%) 으로 발병하는 경우가 더 많았고, insidious onset으로 어지럼 증이 발생한 환자들은 주로 보행 시 균형장애를 주 증상으로 호소하였다. 세부 진단이 Caloric VN인 경우는 $25.0 \%$, Noncaloric VN인 경우가 75.0\%로 Non-caloric VN의 빈도가 3 배 높았다(Table 1).

\section{안진의 양상}

안진의 방향을 분석한 결과 모든 DC VIN 환자에서 자발 안진은 관찰되지 않았다. 두진후안진은 33.3\%(5명)에서 양성 소견을 보였다. 두진후안진의 방향은 등속회전검사의 시간상 수의 방향 우위와 일치하였다. 즉, 등속회전검사에서 시간상

Table 2. Nystagmus of 15 patients with direction changing vibration induced nystagmus and unilateral vestibular hypofunction

\begin{tabular}{|c|c|c|c|c|c|c|c|c|c|}
\hline \multirow{2}{*}{$P$} & \multirow{2}{*}{ Sex/age } & \multirow{2}{*}{$D x$} & \multirow{2}{*}{$\begin{array}{l}\text { Duration } \\
\text { (mo) }\end{array}$} & \multirow{2}{*}{$\begin{array}{l}\text { Dizziness } \\
\text { character }\end{array}$} & \multirow{2}{*}{ SN } & \multirow{2}{*}{$\mathrm{HSN}$} & \multicolumn{3}{|c|}{ VIN } \\
\hline & & & & & & & Right mastoid & Left mastoid & DC VIN \\
\hline P01 & $F / 43$ & Caloric VN & 2.0 & Insidious onset & 0 & 0 & $\mathrm{RB}$ & LB & Ipsi \\
\hline P02 & $M / 68$ & Non-caloric VN & 1.6 & Insidious onset & 0 & LB & $\mathrm{RB}$ & LB & Ipsi \\
\hline P03 & $M / 65$ & SHLV & 1.1 & Insidious onset & 0 & 0 & RB & LB & Ipsi \\
\hline P04 & $\mathrm{F} / 77$ & Non-caloric VN & 12.2 & Insidious onset & 0 & $7 \mathrm{RB}$ & LB & RB & Cont \\
\hline P05 & $M / 68$ & Non-caloric VN & 8.0 & Acute attack & 0 & 0 & LB & $\mathrm{RB}$ & Cont \\
\hline P06 & $F / 60$ & Non-caloric VN & 2.6 & Acute attack & 0 & $7 \mathrm{LB}$ & LB & $\mathrm{RB}$ & Cont \\
\hline P07 & $F / 55$ & Non-caloric VN & 3.6 & Acute attack & 0 & 0 & LB & RB & Cont \\
\hline P08 & $M / 88$ & Caloric VN & 118.2 & Insidious onset & 0 & $5 \mathrm{LB}$ & $\mathrm{RB}$ & LB & Ipsi \\
\hline P09 & $M / 81$ & Caloric VN & 2.0 & Insidious onset & 0 & 0 & LB & RB & Cont \\
\hline P10 & $\mathrm{F} / 74$ & SHLV & 2.3 & Acute attack & 0 & 0 & RB & LB & Ipsi \\
\hline P11 & $M / 66$ & Non-caloric VN & 7.0 & Acute attack & 0 & 0 & LB & RB & Cont \\
\hline P12 & $M / 62$ & Non-caloric VN & 24.5 & Insidious onset & 0 & LB & LB & RB & Cont \\
\hline P13 & $F / 65$ & Non-caloric VN & 16.4 & Acute attack & 0 & 0 & LB & RB & Cont \\
\hline P14 & $\mathrm{F} / 71$ & Non-caloric VN & 0.0 & Insidious onset & 0 & 0 & RB & LB & Ipsi \\
\hline P15 & $F / 68$ & Non-caloric VN & 2.2 & Acute attack & 0 & 0 & $\mathrm{RB}$ & LB & Ipsi \\
\hline
\end{tabular}

'O' means no existing nystagmus. P: patient, VN: vestibular neuritis, SHLV: sudden sensorineural hearing loss with vertigo, SN: spontaneous nystagmus, HSN: post head shake nystagmus, VIN: vibration induced nystagmus, DC: direction changing, RB: right beating nystagmus, LB: left beating nestagnus, ipsi: ipsilateral, cont: contralateral 
DC VIN in Unilateral Vestibular Hypofunction I Lee DH, et al.

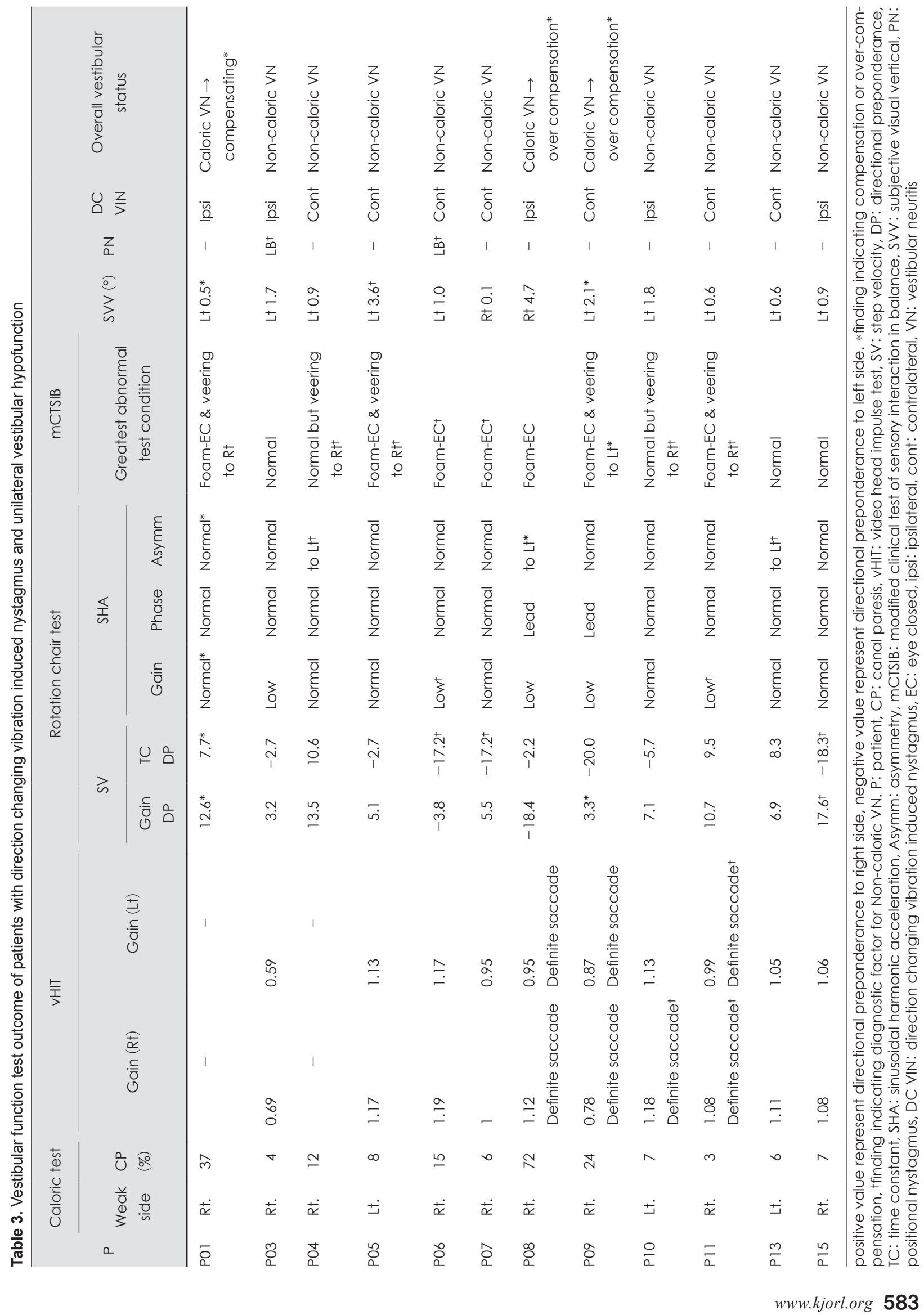


수가 감소한 귀를 병 측으로 간주할 때 두진후안진은 예외 없이 건 측을 향하였다. 환자들의 DC VIN은 두 가지 방향 성을 보였다. 첫째 진동 자극이 주어진 귀를 향해 안진이 나 타나는 경우(ipsilateral DC VIN, ipsi-DC VIN)와, 둘째 진 동 자극이 주어진 반대쪽 귀를 향해 안진이 나타나는 경우 (contralateral DC VIN, cont-DC VIN)가 있었다. 46.7\%(7명) 은 ipsi-DC VIN에 해당하였으며, 53.3\%(8명)는 cont-DC VIN 에 해당하였다(Table 2).

\section{전정기능검사 결과}

Caloric VN 환자들의 온도안진검사 결과는 정의상 모두 반 고리관 마비가 $>20 \%$ 이었다. Caloric VN 환자들의 회전의 자검사 결과는 이미 중추신경계 보상이 진행된 일측 전정기 능 저하에 부합하였다(Table 3). 즉, 정현파회전검사 혹은 등 속회전검사 비대칭이 이미 정상화되었거나(33.3\%), 오히려 비 대칭이 건 측으로 치우친 과보상(over compensation) 상태였 다(66.7\%). Non-caloric VN 환자들은 온도안진검사 반고리 관 마비 값이 정상 $(<20 \%)$ 이었으나, 회전의자검사, 두위안진, 비디오두부충동검사 또는 $\mathrm{mCTSIB}$ 검사에서 전정기능의 좌 우 불균형이 확인되어 경미한 전정기능 저하가 있는 것으로 판단하였다. mCTSIB 결과는 대부분 환자(58.3\%, 7/12)에서 전정 병증을 시사하는 조건에서 주로 문제가 발견되었다. 그 러나 난형낭의 정적 좌우 불균형을 반영하는 주관적시수직 검사는 $83.3 \%(10 / 12)$ 에서 정상으로 판명되었다.

\section{Ipsi-DC VIN과 cont-DC VIN의 임상양상}

$\mathrm{ipsi}-\mathrm{DC} \operatorname{VIN}(\mathrm{n}=7)$ 군과 contra-DC VIN(n=8) 군을 비교 했을 때, 나이(68.1 \pm 13.4 세 vs. $66.8 \pm 8.6$ 세, $p=0.450)$, 성별 (male 3, female 4 vs. male 4, female 4, $p=0.782$ ), 어지러움 발병양상(acute attack 2, insidious onset 5 vs. acute attack 3 , insidious onset $5, p=0.741$ ), 온도안진검사 결과(Normal 3, Abnormal 2 vs. Normal 6, Abnormal 1, $p=0.312$ ), 회전의자 검사 결과(Normal 3, Abnormal 2 vs. Normal 2, Abnormal $5, p=0.274)$ 에서의 유의한 차이는 없었다. 단, 유병 기간을 첫 번째 증상이 발생한 시점부터 외래에 내원하여 VIN 검사를 시행하기까지의 기간으로 정의할 때 ipsi-DC VIN 환자의 유병 기간이 18.2 \pm 44.1 개월로, cont-DC VIN 환자들의 9.5 \pm 7.8 개월보다 길었다 $(p=0.043)$. 안진의 방향과 병 측을 비교한 경 우 ipsi-DC VIN 환자들은 건 측을 자극할 때 전정신경염 자 발 안진 방향과 일치하는 방향의 VIN이 유발되었다.

\section{고 찰}

고찰에 앞서 본 연구가 기존의 연구에 대해 가지는 의의를 제시해보자면, 저자들이 아는 한 본 연구는 pathologic DC VIN에 집중하여 그 존재를 규명하고 임상 양상과 기전을 분 석하려고 노력한 최초의 보고이다. 기존의 논문들은 모두 일 측 전정기능 저하 환자에서의 VIN을 연구하던 중 발견된 환 자를 일부 언급하는 수준이거나 정상인에 대해서만 해당 소 견에 대한 언급이 있었다. 또한, 본 연구는 DC VIN의 기전을 규명하기 위해 골도 전도의 이간 감쇄 효과를 고려한 최초의 보고라고 생각된다. 기존의 논문들은 모두 cervico ocular reflex(COR)에 의한 기전만을 명시하였다.

\section{일측 전정기능 저하 환자에서 진동유발 안진의 방향}

이전 연구들은 모두 일측 전정기능 저하 환자에서의 VIN 이 건 측을 향한다고 보고하였다. ${ }^{2,45}$ 예를 들어 Ohki 등근 100 명의 일측 전정기능 저하 환자 중 $60 \%$ 에서 진동유발 안 진이 발현되었으며, 반고리관 마비가 $50 \%$ 이상인 환자에서 는 VIN 발현율이 $90 \%$ 이상이라고 보고하였다. 안진의 방향 은 대다수(78.3\%)에서 건 측 방향이라고 하였다. Park 등ㄴ)은 19 명의 전정신경염 환자에서 좌우 유양돌기 어느 쪽을 자극 하더라도, VIN이 유발되지 않은 1명(5.3\%)을 제외하면 나머 지 18 명 $(94.7 \%)$ 모두에서 건 측을 향하는 안진이 유발된다고 보고하였다. Xie 등ㄱ은 일측 전정병증 환자에서, 메니에르병 의 경우를 제외하면 54명 중 6명(11.1\%)은 VIN이 유발되지 않 았으나 나머지 48명(88.9\%)에서는 VIN이 모두 건 측을 향했 다고 보고하였다.

그러나, 본 연구자들의 경험에 따르면 VIN을 시행한 환자 315 명 중 18 명 즉, $5.7 \%$ 에서 $\mathrm{VIN}$ 의 방향이 자극 귀에 따라 서로 바뀌는 DC VIN이 관찰되었다. 기존 보고에서 VN환자 에서 DC VIN의 가능성이 간과된 이유는 아마도 DC VIN 의 발견 빈도가 매우 낮기 때문이라고 생각된다. 본 연구는 315 명을 대상으로 분석하였으며 기존 보고들보다 표본이 커 서 드문 현상인 DC VIN을 18 명에서 발견할 수 있었던 것으로 생각된다. 또 다른 이유로는 본 연구에서 Non-caloric VN을 연구 대상에 포함했기 때문으로 생각된다. DC VIN 환자들 은 유병 기간이 평균 $13.6 \pm 29.7$ 개월로 오래된 전정신경염 환 자들이 많았으며, 전체 DC VIN 환자 중 세부 진단이 Caloric $\mathrm{VN}$ 인 환자는 Non-caloric VN의 1/3에 불과하였다. 또 Caloric $\mathrm{VN}$ 환자들은 모두 회전의자검사와 두부충동검사 결과 이미 보상이 이루어졌거나 과보상 상태로 전환 중이었다. 즉, $\mathrm{DC}$ $\mathrm{VIN}$ 은 전형적인 급성기 전정신경염보다는 전정기능 저하가 경미한 전정신경염(75\%) 또는 보상기 전정신경염(25\%)에서 
관찰될 가능성이 더 높았다. 기존 보고들은 Caloric $\mathrm{VN}$ 만을 대상으로 하였기 때문에 아마도 DC VIN의 발견이 더욱 어려 웠을 것으로 추정된다. 본 연구의 결과에 따르면, 일측 전정 기능저하 환자에서의 VIN이 건 측을 향하는 경우가 많지만 (94.3\%), 드물게는 $5.7 \%)$ 자극 부위에 따라 안진 방향이 바 뀔 수 있다는 것이 더 올바른 정보가 될 것으로 생각된다.

\section{정상인에서의 진동유발안진}

일측 전정기능 저하 환자의 VIN에 대해서는 여러 연구자가 일관된 보고를 한 것과는 달리, 정상인의 VIN에 대해서는 연구자마다 다양한 의견을 보고한다. Hamann과 Schuster ${ }^{13}$ 는 정상인에서 VIN이 전혀 나타나지 않는다고 보고하였으 며, Michel 등근 정상인의 6\%에서 VIN이 발생 가능하지만 30세 이하에서 발생한 경우는 없었다고 보고하였다. Xie 등 5 은 정상인 30명을 조사하였을 때 진동유발안진이 없었다고 보 고하였다. 그러나 이상의 보고들과 달리 정상인에서도 VIN이 자주 발견된다는 보고들도 있다. Perez ${ }^{6}$ 는 정상인의 $80 \%$ 에 서 진동유발안진이 발현되지만 모든 피험자에서 안진의 크기 가 $2.8 \%$ 를 넘지 않아 전정병증 환자들 $35 \%$ 에서 안진의 크 기가 $2.8 \%$ 이상)과 구분된다고 하였다. Park 등 ${ }^{4}$ 도 22 명의 정 상인에서 우측 유양돌기 자극 시 13명(59.1\%)에서 진동 유발안 진이 나타났으며 평균 안진의 방향이 좌측방향 $(-1.5 \%)$ 이었으 며, 좌측 유양돌기 자극 시에는 11 명(50\%)에서 진동유발안진 이 나타났으며 평균 안진의 방향이 우측 $(0.4 \%)$ 이었음을 보 고하였으나 전정신경염 환자에서 나타난 안진(우측 유양돌기 자극 시 $10.4 \%$, 좌측 유양돌기 자극 시 $10.8 \%$ )보다는 크기가 작았다고 하였다. 이들은 VIN이 일어나는 메커니즘으로 정상 인에서는 경부 고유감각에 의한 COR이 VIN을 일으키는 주 된 역할을 하며 일측 전정기능 저하 환자에서는 vestibulo ocular reflex(VOR)가 VIN을 일으키는 주된 역할을 할 것 이라고 추론하였다. 즉, 정상인에서 VIN이 어떻게 나타나는 지에 대해서는 아직까지 연구자들마다 이견이 있지만, 일반 적으로는 정상인에서는 VIN이 나타나지 않거나 나타나더라 도 그 크기가 작은 것으로 생각된다. 그러나 연구마다 결과가 일관되지 않아 향후 정상인에서의 VIN 결과는 추가 연구가 필요할 것으로 생각된다.

\section{진동유발안진의 발생원리}

진동유발안진의 발생기전에 대해서는 아직 논란이 있다. 대표적 가설 중 하나는 골 전도를 통한 진동을 주면 양측 미 로의 전정 감수기를 동시에 자극하게 되고 이로부터 구심성 전 정신경을 통해 뇌간으로 신호가 전달되게 되는데 일측 전정 기능 저하가 있으면 전정신경핵으로 전달되는 신호에 비대칭
이 발생하여 정상 측을 향하는 안진이 나타나는 것이다.,14) 구심성 신호의 비대칭 이론은 전정기능의 비대칭이 있는 환자 에서 두진후안진이 발생하는 기전과 비슷하다. 즉, Ewald의 제2 법칙과 속도 저장 기전(velocity storage mechanism)에 의 해 두진 혹은 진동이 반복되면 좌우 전정신경핵에 축적되는 정보량에 차이가 발생하여 안진이 유발된다. 온도안진검사의 안진 발생 기전과 VIN의 구심성 신호의 비대칭 이론 사이에 는 일부에서 차이가 있다. Ulmer 등든 은 온도안진검사와 같은 저주파의 자극은 말초 전정 수용기의 긴장성 세포(tonic cell) 를 우선적으로 자극하는 반면에 고주파의 진동 자극은 팽대 부릉정(cupula)과 전정 평형반(vestibular maculae)의 위상 세포(phasic cell)를 더 자극할 것이라고 추측하였다. 또 온도 안진검사는 검사를 반복할 때 적응 현상이 관찰되는 반면 진 동유발안진에서는 적응 현상이 관찰되지 않는다는 점은 둘 의 발생기전에 차이가 있음을 시사한다. ${ }^{13,16)}$

한편, Hamann과 Schuster ${ }^{13)}$ 는 진동유발안진이 정상인이나 central vertigo 환자에서는 나타나지 않기 때문에 진동유발 안진의 수용기가 내이 전정일 것으로 추정하였다. 그러나 정확 히 어떤 세포가 주된 역할을 하는지는 알 수 없다고 하였고 또 한 내림프의 파동이 안진 유발의 유일한 기전인지 아니면 감 각신경 세포의 직접적인 흥분도 역할을 할 것인지도 불분명 하다고 하였다. 다만, 진동유발안진이 수평 방향으로 주되게 나타나긴 하지만 작은 회선 성분을 가지므로 반고리관이 진 동유발 안진을 일으키는 주된 역할을 하고, 이석기관의 수용 기가 일부 관여할 수도 있을 것이라고 추정하였다. Hamann 과 Schuster ${ }^{13)}$ 는 이상과 같은 정보들로부터 진동유발안진의 수용기가 온도안진검사의 수용기와 동일하기 때문에 검사 해 석의 측면에서 바라보았을 때 동일한 정보를 제공 한다고 설 명하였다. 이를 뒷받침하는 또 다른 증거로 전정기능이 완전 히 소실된 labyrinthine-defective 환자에서는 VIN이 나타나 지 않는다는 보고가 있다. ${ }^{17)}$ 이처럼, 진동유발 안진은 진동이 반고리관을 자극하여 발생하는 것으로 생각되며, 일측 전정 기능 저하 시 전정신경 핵으로 전달되는 신호의 비대칭이 발 생하기 때문에 안진이 발생한다는 점에서는 온도안진검사와 원리가 유사하다고 생각된다.

\section{자극 측 방향전환 진동유발안진(ipsi DC VIN)의 기전 (mechanism)에 대한 추정}

저자들은 ipsi-DC VIN의 기전으로, 진동 자극의 이간감쇄 (interaural attenuation of vibration)가 전정기능 비대칭의 정 도(amount of vestibular asymmetry)보다 큰 경우 ipsi-DC $\mathrm{VIN}$ 이 나타나는 것으로 추정하였다. 전형적인 급성 전정신 경염의 경우 전정기능 비대칭의 정도가 크기 때문에 진동 자 
극이 발생하면, 어느 귀를 자극하더라도 건 측 귀에 인가되는 진동 전정자극의 크기가 병 측 귀에 인가되는 진동 전정자극 의 크기보다 크다. 즉, 어느 귀를 자극하더라도 건 측을 향하 는 VIN이 발생한다. 한편, DC VIN이 나타난 환자들은 모두 전정기능 저하가 경미한 전정신경염(75\%) 또는 보상기 전정신 경염(25\%)이므로 전정기능 비대칭의 정도가 작았던 환자들 이다. 전정기능의 비대칭이 작은 경우 진동 자극은 이간 감약 에 의해 진동기에서 가까운 귀는 인가되는 진동 전정자극의 크기가 크고, 진동기에서 먼 귀는 인가되는 진동 전정자극의 크기가 상대적으로 작아지게 된다. 정상인은 양측 전정 기능 이 안정적이므로 좌우 전정 신호의 미세한 비대칭을 충분히 극복하지만, 전정기능의 비대칭이 존재하는 환자인 경우는 양측 전정 기능이 불안정하여 진동기에서 가까운 귀가 더 강 하게 자극되고 이로 인해 ipsi-DC VIN이 발생하는 것으로 추정된다. 설명을 돕기 위해 Fig. 1에서 좌우 귀의 전정기능 (vestibular function)을 흰색 막대의 높이로 나타내고 진동 에 의한 전정자극을 검은 막대로 표시하였다. 우측 전정신경 염 환자를 가정했을 때 진동 자극의 이간 감쇄가 $0 \mathrm{~dB}$ 이라 면 검은 막대의 크기가 같으므로, 우측 전정자극이 좌측보 다 작게 되어 좌측으로 향하는 VIN이 나타난다. 이는 기존 문헌에서 알려진 전형적인 VIN과 합당한 결과이다(Fig. 1). 그러나 실제로는 진동 자극에 대한 이간 감쇄가 $0 \sim 10 \mathrm{~dB}$ 이 기 ${ }^{18)}$ 때문에 전정자극(검은막대)이 진동을 가하는 동측에서 더 크다. 따라서 전정기능 비대칭의 정도가 작으면 이간 감쇄 의 영향으로 안진의 방향이 역전되는 상황이 생길 수 있다. 우측 유양돌기 자극 시 동측 자극이 더 커지면서 좌측을 역 전하여 우측으로 향하는 안진이 나타나고, 좌측 유양돌기 자 극 시 전정 활성의 차이는 원래보다 더 벌어지며 좌측으로 향 하는 안진이 나타나게 되어 진동을 가한 쪽으로 안진이 향하

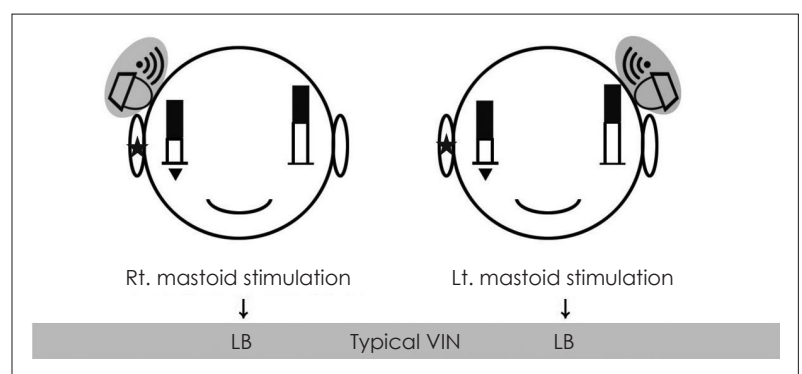

Fig. 1. Presumed mechanism of typical VIN for mild Rt. VN patient (If interaural attenuation is "0"). White bars mean right and left vestibular function, and black bars mean vibration induced vestibular stimulations. The height of right white bar is lower than left one. Because interaural attenuation is assumed as "0," all added black bars have same height. So, regardless of the vibration side, Rt VN patient shows left sided nystagmus. Asterisks indicate phathologic side, and Inverted triangle mean weaker vestibular function compared to opposite side. VIN: vibration induced nystagmus, VN: vestibular neuritis.
는 자극측 방향전환 진동유발안진(ipsi DC VIN)이 나타날 수 있을 것이다(Fig. 2).

본 연구의 한계점은 첫째, 안진의 크기를 정량적으로 분석 하지 못하였다. 본 연구에 포함된 자료는 대부분 동영상으로 기록/저장된 자료로 정량분석에 필요한 보정 과정이 누락되 어 후향적으로 안진의 크기를 평가하는 것이 불가능하였다. 기존 보고들에 따르면 냉온교대안진검사에서의 반고리관 마 비의 정도와 VIN의 강도가 양의 상관관계를 보여 VIN 크기 가 전정기능 저하의 정도를 평가하는 척도로 사용될 수 있는 것으로 추정된다. ${ }^{19}$ 또 정상인에서 $\mathrm{VIN}$ 이 발견되더라도 그 크기가 $2.8 \%$ 이하였다는 보고 ${ }^{6}$ 등을 참고할 때, 전정신경염 환자에서 DC VIN을 보이는 환자에서의 안진 크기가 $2.8 \%$ 보다 큰지 여부를 확인하는 과정이 추후 필요할 것으로 생각 된다.

둘째, 저자들의 가설은 ipsi-DC VIN을 설명할 수 있지만, contra-DC VIN에는 적용이 불가능하다. 그런데, 기존 연구에 서 정상인의 경우 진동을 가한 반대쪽으로 약한 VIN이 나타 난다고 보고하였으며 이러한 방향성은 본 연구의 contra-DC $\mathrm{VIN}$ 환자에서 관찰한 방향성과 일치한다. 따라서 정상인 및 contra-DC VIN 환자에서는 COR의 영향이 VOR보다 우세 하게 작용하였다고 생각해 볼 수 있다. 반면, 전형적인 일측 전정기능 저하 환자에서는 $\mathrm{COR}$ 보다는 $\mathrm{VOR}$ 의 영향이 더 우 세하게 작용하고, ipsi-DC VIN 환자에서는 진동의 전달과정 에서 발생하는 이간 감쇄의 영향으로 인하여 ipsi-DC VIN이 발생하는 것으로 추정된다. 그러나 왜 어떤 환자들은 $\mathrm{VOR}$ 이 더 우세하게 작용하고 다른 환자들과 정상인에서는 $\mathrm{COR}$ 이

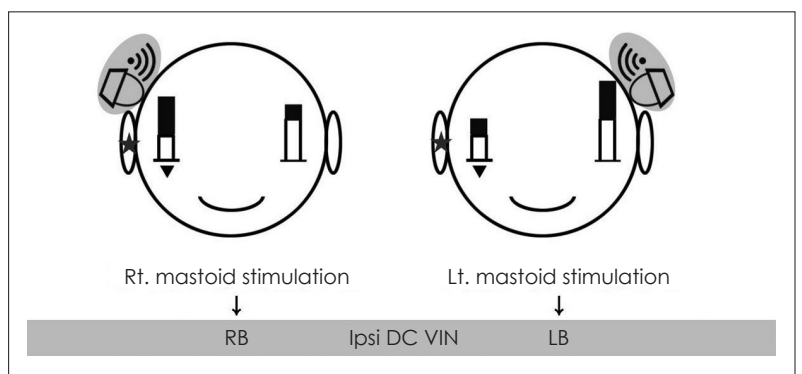

Fig. 2. Presumed mechanism of ipsi DC VIN for mild Rt VN patient (If interaural attenuation is not "0"). White bars mean right and left vestibular function, and black bars mean vibration induced vestibular stimulations. The height of right white bar is lower than left one. In this figure, because interaural attenuation is assumed as "not 0 ," black bar height of vibration side is higher than the opposite side. So, when the vibration is induced on the right side, final vestibular activation of right side overtakes the left side, and patient shows right sided nystagmus. Asterisks indicate phathologic side, and Inverted triangle mean weaker vestibular function compared to opposite side. *interaural attenuation of bone conduction pure tone $(250-4000 \mathrm{~Hz})$ : $0-10 \mathrm{~dB}$ (Ballenger's Otorhinolaryngoly: Head and Neck Surgery, Chapter 9, p.129). DC: direction changing, VIN: vibration induced nystagmus, VN: vestibular neuritis. 
우세하게 작용하는지에 대해서는 여전히 설명이 어려운 점이 있고 이러한 추정 기전을 뒷받침하기 위해서는 추가적인 연 구가 향후 더 필요할 것으로 생각된다.

셋째, 환자들의 유병 기간이 대체로 너무 길고 DC VIN의 발현빈도가 약 $5 \%$ 로 적어, 급성기 전정신경염 환자에서 $\mathrm{DC}$ VIN이 측별 진단의 선별도구로서 어떤 임상적 의미가 있는 지 평가하는 데 한계가 있었다. 의도적으로 유병 기간이 긴 환자만을 연구한 것은 아니지만, DC VIN이 발견된 환자들 은 모두 유병 기간이 매우 길었고 이는 아마도 위에서 설명 한 바와 같이 부분적인 보상이 진행된 상태에서 DC VIN이 잘 유발되기 때문으로 추정된다. 그러나 전정신경염 발병 1 개 월에서 12 개월 사이의 환자에서 시간이 지나도 진동 유발 안 진의 강도가 유의하게 바뀌지 않는다는 보고 ${ }^{19)}$ 를 미루어볼 때 최소 1 12개월 사이에서는 DC VIN의 재현성이 문제가 되지는 않을 것으로 추정된다.

\section{Acknowledgments}

This work was supported by the general research funding of the Seoul National University Hospital [No. 0420160860 (2016-1151)].

\section{REFERENCES}

1) Lücke $\mathrm{K}$. [A vibratory stimulus of $100 \mathrm{~Hz}$ for provoking pathological nystagmus (author's transl)]. Z Laryngol Rhinol Otol 1973;52(10): 716-20.

2) Ohki M, Murofushi T, Nakahara H, Sugasawa K. Vibration-induced nystagmus in patients with vestibular disorders. Otolaryngol Head Neck Surg 2003;129(3):255-8.

3) Michel J, Dumas G, Lavieille JP, Charachon R. Diagnostic value of vibration-induced nystagmus obtained by combined vibratory stimulation applied to the neck muscles and skull of 300 vertiginous patients. Rev Laryngol Otol Rhinol (Bord) 2001;122(2):89-94.

4) Park H, Shin J, Shim D. Mechanisms of vibration-induced nystagmus in normal subjects and patients with vestibular neuritis. Audiol Neurootol 2007;12(3):189-97.

5) Xie S, Guo J, Wu Z, Qiang D, Huang J, Zheng Y, et al. Vibration- induced nystagmus in patients with unilateral peripheral vestibular disorders. Indian J Otolaryngol Head Neck Surg 2013;65(4):333-8.

6) Perez N. Vibration induced nystagmus in normal subjects and in patients with dizziness. a videonystagmography study. Rev Laryngol Otol Rhinol (Bord) 2003;124(2):85-90.

7) Jung JY, Kim YH, Suh MW. Difference in the nature of dizziness between vestibular neuritis and sudden sensorineural hearing loss with vertigo. Otol Neurotol 2012;33(4):623-8.

8) Han JJ, Hong S, Park H, Koo JW, Lee JH, Oh SH, et al. Preoperative vestibular function in adults with cochlear implantation: comparison between prelingual and poslingual deafness. Korean J OtorhinolaryngolHead Neck Surg 2014;57(2):89-95.

9) Yang CJ, Lee JY, Kang BC, Lee HS, Yoo MH, Park HJ. Quantitative analysis of gains and catch-up saccades of video-head-impulse testing by age in normal subjects. Clin Otolaryngol 2016;41(5):532-8.

10) Normative data for the balance master system [computer program]. Seattle (WA): Natus;2017.

11) Wuyts FL, Furman J, Vanspauwen R, Van de Heyning P. Vestibular function testing. Curr Opin Neurol 2007;20(1):19-24.

12) Cousins S, Kaski D, Cutfield N, Arshad Q, Ahmad H, Gresty MA, et al. Predictors of clinical recovery from vestibular neuritis: a prospective study. Ann Clin Transl Neurol 2017;4(5):340-6.

13) Hamann KF, Schuster EM. Vibration-induced nystagmus-a sign of unilateral vestibular deficit. ORL J Otorhinolaryngol Relat Spec 1999;61(2):74-9.

14) Young ED, Fernández C, Goldberg JM. Responses of squirrel monkey vestibular neurons to audio-frequency sound and head vibration. Acta Otolaryngol 1977;84(5-6):352-60.

15) Ulmer E, Chays A, Brémond G. [Vibration-induced nystagmus: mechanism and clinical interest]. Ann Otolaryngol Chir Cervicofac 2004;121(2):95-103.

16) Barnes G. Adaptation in the oculomotor response to caloric irrigation and the merits of bithermal stimulation. Br J Audiol 1995;29(2):95-106.

17) Dumas G, Schmerber S, Lavieille JP. [Nystagmus and vibratory test: evidence for mechanism. Material conditions and methods in the fast detection of unilateral vestibular lesions]. Ann Otolaryngol Chir Cervicofac 2003;120(5):286-95.

18) Snow JB. Ballenger's manual of otorhinolaryngology head and neck surgery. Shelton: Pmph usa;2003.

19) Koo JW, Moon IJ, Hong SL, Moon SY, Choi KD, Kim JS. Clinical significance of vibration-induced nystagmus in unilateral peripheral vestibular loss. Korean J Otorhinolaryngol-Head Neck Surg 2006;49 (9):897-903. 